\title{
Recension av Den lilla socknen i det stora Sverige. Folket $i$ Döderhult på 1600-talet av Gunnar Källenius, Oskarshamn, 1999.
}

\author{
Av Olle Larsson, fil.dr i historia
}

Länk till presentation av Olle Larsson

Hur tedde sig livet för människorna i en svensk socken under den svenska stormaktstiden? I Gunnar Källenius historik över Döderhults socken under 1600-talet besvaras denna fråga på ett förtjänstfullt sätt. Genom en minst sagt imponerade källgenomgång låter författaren socknens människor och deras levnadsvillkor träda fram för den nutida läsaren. Fjärran från blodiga slagfält, dånande fältkanoner, fladdrande fanor, stinkande fältläger och garnisoner levde människorna i denna socken i skuggan av det svenska stormaktsväldet.

Författaren pendlar genom hela boken mellan det stora och det lilla, mellan den nationella historien och den lokala. Källenius berör i stort sett alla aspekter av 1600-talsmänniskans liv i sin bok. Han ger oss kunskaper om socknens gårdar och deras skattekraft liksom om näringarna i stort. Ett myller av människor möter oss under läsningen. Vi får träffa sockenpräster, krigsfolk, brottslingar och fattighjon. Relationen mellan man och kvinna beskrivs i ett avsnitt om familjen och äktenskapet. Att vänskap inte alltid rådde mellan grannar och sockenbor framgår tydligt i kapitlet om brott och straff. I affekt kunde människorna kalla varandra för både det ena och det andra. Källenius ger bland annat en provkarta på de okvädingsord som kunde utväxlas. Hundsvott, tjockhals, tjuv, fyllehynda, fjärdingsfitta och knäfis är exempel på tillmälen som kunde användas i stridens hetta. I bokens avslutande kapitel låter författaren oss ta del av några konkreta människoöden. Framför våra ögon spelas bland annat mordet på Jöns Svensson i Äshult upp. Vi får uppleva det stora slagsmålet i Lilla Hycklinge 1641 och möta den olyckliga pigan Karin Månsdotter som en majdag 1698 inte orkade leva längre.

Källenius bok ger en mycket god bild av hur livet i en svensk socken kunde gestalta sig under den svenska stormaktstiden. Källgenomgången imponerar liksom det spänstiga språk som präglar boken. Genom bokens detaljrikedom kan alla, såväl fackhistoriker som hembygdsforskare och släktforskare, hitta riktiga godbitar. Min enda kritiska anmärkning mot boken är att den saknar noter, vilket gör att det blir mycket svårt för läsaren att själv gå till källorna och hitta den information som författaren ger i texten. Det bestående intrycket av boken är dock mycket positivt. Det är kort sagt ett stycke lokalhistoria av bästa märke som Källenius givit oss genom sin bok. I egenskap av 1600-talshistoriker av facket kan jag bara ge boken högsta betyg och rekommendera den till läsning för alla som är intresserade av detta händelserika och omvälvande skede i vår historia.

(C) Olle Larsson 